\title{
The Role of Smart Working in Mediating Participatory Altruistic Leadership, Competence, Quality knowledge in Learning Performance of Lecturers in Higher Education
}

\author{
Sri Handayani ${ }^{1}$, DYP Sugiharto ${ }^{1}$, Joko Sutarto ${ }^{1} \&$ Kardoyo $^{1}$ \\ ${ }^{1}$ Doctoral Program of Education Management Departement, Universitas Negeri Semarang, Semarang, Indonesia \\ Correspondence: Sri Handayani, ${ }^{1}$ Doctoral Program of Education Management Departement, Universitas Negeri \\ Semarang, Semarang, Indonesia.
}

Received: July 9, 2020

Accepted: August 13, 2020

Online Published: August 18, 2020

doi:10.5430/ijhe.v9n5p346

URL: https://doi.org/10.5430/ijhe.v9n5p346

\begin{abstract}
This study aims to explore indicate that lecturer learning performance is an important factor for lecturers in the Civil Engineering Education Study Program. Participatory altruistic leadership styles, competence, quality knowledge, smart working are very important to be measured to explain their effects on learning performance. If the lecturer has high competence and quality knowledge and is supported by appropriate leadership, it will have an impact on smart working, which in the end will achieve learning performance. This research was conducted of lecturers of civil engineering education throughout Indonesia and a sample of 76 peoples. The research method was conducted with quantitative and data analysis using structural equation modeling (SEM). Regression coefficient result that relationship between competence with smart working, participatory altruistic with smart working and quality of knowledge with smart working were $0.80,0.86$ and 0.81 . Regression coefficient result that relationship between smart woking with learning performance, participatory altruistic with learning performance, quality knowledge with smart working and competence with smart working were $0.99,0.91,0.88$, and 0.88 .
\end{abstract}

Keywords: competence, learning performance, participatory altruistic, quality knowledge, smart working

\section{Introduction}

\subsection{Problem Identification}

Lecturer learning performance is influenced by the ability of individuals to manage their abilities. The ability of each lecturer depends on the level of quality knowledge possessed, professionalism, sense of social in communicating and dealing with colleagues and students (Babalola, 2016). Lecturer learning performance is related to the quality of individuals in higher education. Learning performance will affect the quality of a study program in a university. Lecturer learning performance is an achievement generated in accordance with the passion and expertise of the lecturer (Nasir et al., 2018). Productive behavior is the employees who deliberately hinder the fulfillment of organizational goals that contribute negatively to the organization (Hussain et al., 2016). Pedagogy and other lecturers' competencies influence learning performance. Stakeholders, students and the community will be motivated by lecturers who have good competence. So that lecturer competence becomes an important factor in learning performance for the development of quality human resources. The orientation of the lecturer and the intelligent work of the lecturer in planning, making formulations, implementing good plans that have been prepared and then willing to conduct evaluations in carrying out their performance affect the quality of the study program. Expertise, skills in self-management and interacting with the surrounding environment become added value for lecturers in learning performance (Sugiharto et al., 2018). Lecturer learning performance can take place well if supported by leadership that supports the development of lecturer performance. The leadership style possessed by leaders in universities determines whether an institution develops. The revolutionary era 4.0 that must be faced by universities had an impact on changes in the pattern of appropriate leadership styles to be implemented to support lecturer learning performance (Handayani et al., 2019). From various leadership theories, the style of participatory altruistic leadership can be a reference for university leaders. The participatory altruistic leadership style will be perfect if it is collaborated with the path goal and spiritual leadership style. (Hussain et al., 2016; Kardoyo et al., 2018; Hallinger \& Hammad, 2019; Pio \& Tampi, 2018; Saide et al., 2019; Pourmola et al., 2019). Waheed and Khaur (2016) indentifyng the quality knowledge into intrinsic, contextual and actionable qualities. Referring to the learning 
performance theory, learning performance is formally defined as the value of the set of lecturer behaviors that contribute, either positively or negatively, to organizational goal accomplishment (Hussain et al., 2016). Those behaviors are generally fit into three broad categories to organization(Kumpulainen et al., 2019; Purwanto et al., 2019). Task performance includes the behavior of employees who are directly involved in the transformation of organizational resources(Handayani et al., 2019).

\subsection{Framework Analysis}

Based on the novelty concept of learning performance, which gave rise to a new concept of smart working this study will discuss the relationship and its influence between participatory altruistic leadership, quality knowledge, and competence of lecturers performance(Famakin \& Abisuga, 2016). Each of these leadership styles is taken in one aspect and combined into participatory altruistic leadership as novelty in research. Some research questions are formulated as following: there is a relationship between the quality knowledge with smart working. There is an influence between the competence of lecturers on smart working. There is an influence between participatory altruistic leadership to smart working. There is an influence between smart working on lecturer performance. There is an influence on the quality knowledge on the learning performance. There is an influence between participatory altruistic leadership on learning performance (Male et al., 2019). There is an influence between lecturer competence on learning performance. Lecturer competencies which include pedagogical competence, professional competence, social competence and personality will influence lecturers' behavior and performance including lecturer learning performance (Sutarto et al., 2017). Indirectly both the quality knowledge, competence of lecturers and participatory altruistic leadership will form a situation and a good understanding of the lecturers, namely intelligent performance and subsequently expected to have an impact on lecturer learning performance (Purwanto et al., 2019). This explains that there is a tendency for lecturer learning performance to be influenced by the quality knowledge, lecturer competence and participatory altruistic leadership through the intelligent learning performance (Pio \& Tampi, 2018). The following will explain the relationship between variables in research on figure 1 .

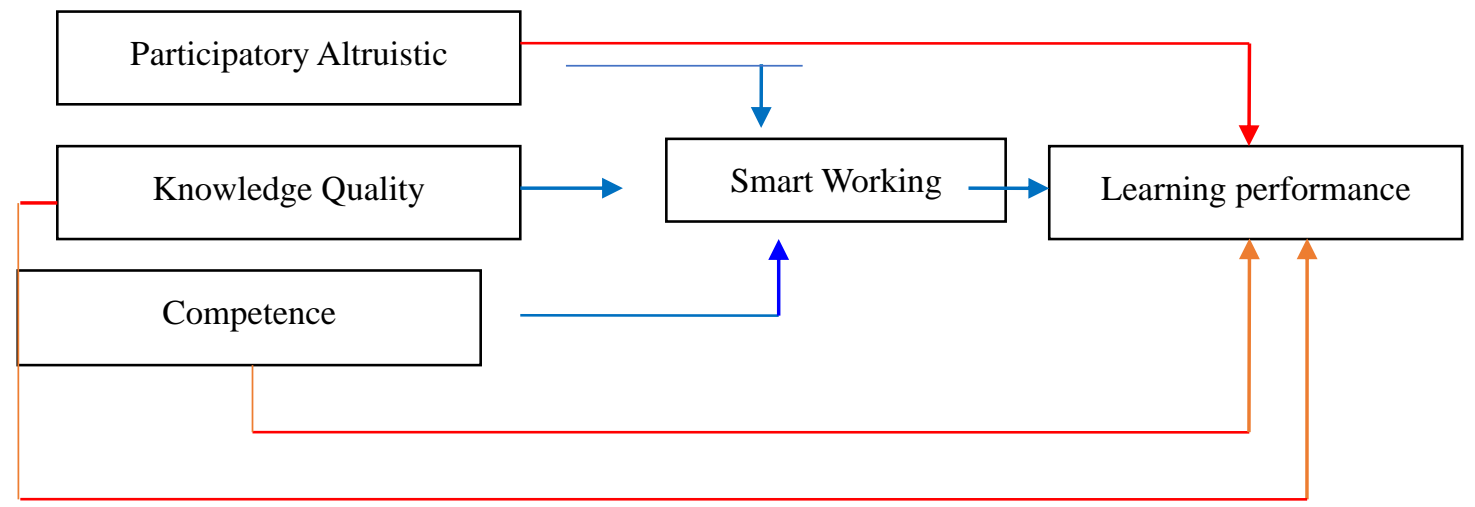

Figure 1. Framework of thinking

\subsection{Hypothesis}

H1: there is relationship between competence and smart working.

$\mathrm{H} 2$ : there is relationship between participatory altruistic leadership and smart working

H3: there is relationship between quality knowledge and smart working

$\mathrm{H} 4$ : there is relationship between smart working and learning performance

H5: there is relationship between quality knowledge and leraning performance

H6: there is relationship between participatory altruistic and learning performance

H7: there is relationship between competence and learning performance

\section{Method}

The population in this study were lecturers in the Civil Engineering Education Study Program throughout Indonesia. The questionnaire instrument was carried out on 76 respondents. The data collection technique of this research was carried out using questionnaire technique. This technique is done by using a questionnaire to reveal the data needed in research that includes data: altruistic participatory leadership, quality knowledge, lecturer competence, smart 
working and lecturer learning performance. Questionnaires were distributed online because of the Covid-19 pandemic

Analysis of the data used in this study is the full model of Structural Equation Modeling (SEM) by first testing its dimensions with confirmatory factor analysis which is the first step in the SEM analysis process. Confirmatory Factor Analysis is a form of a measurement model that models the relationship variables. The purpose of the measurement model is to describe how well these indicators can be used as instruments for measuring variables. In Structural Equation Modelling (SEM) analysis, the relationship between variables and observed variables is reflective, where the observed variables are a reflection of variables (Milhem, Muda, \& Ahmed, 2019)

After checking all of estimation carefully, the researcher did not find more than one negative error variance and standard of loading factors. In addition there is no standard error of great value. With these results, all variables have met good conditions in the absence of an offending estimate (Sarstedt et al., 2019). Test the validity and reliability in the SEM analysis on the Lisrel program can be done using a measurement model. Combination of all SEM components into a complete model flowcharts (Path Diagram) or Hybrid Model. Path diagram describe the research model in the form of mathematical notation (Sarstedt et al., 2019). This model shows the relationship between indicator variables and their variables in the Pathway Hybrid Model as shown in Figure 2

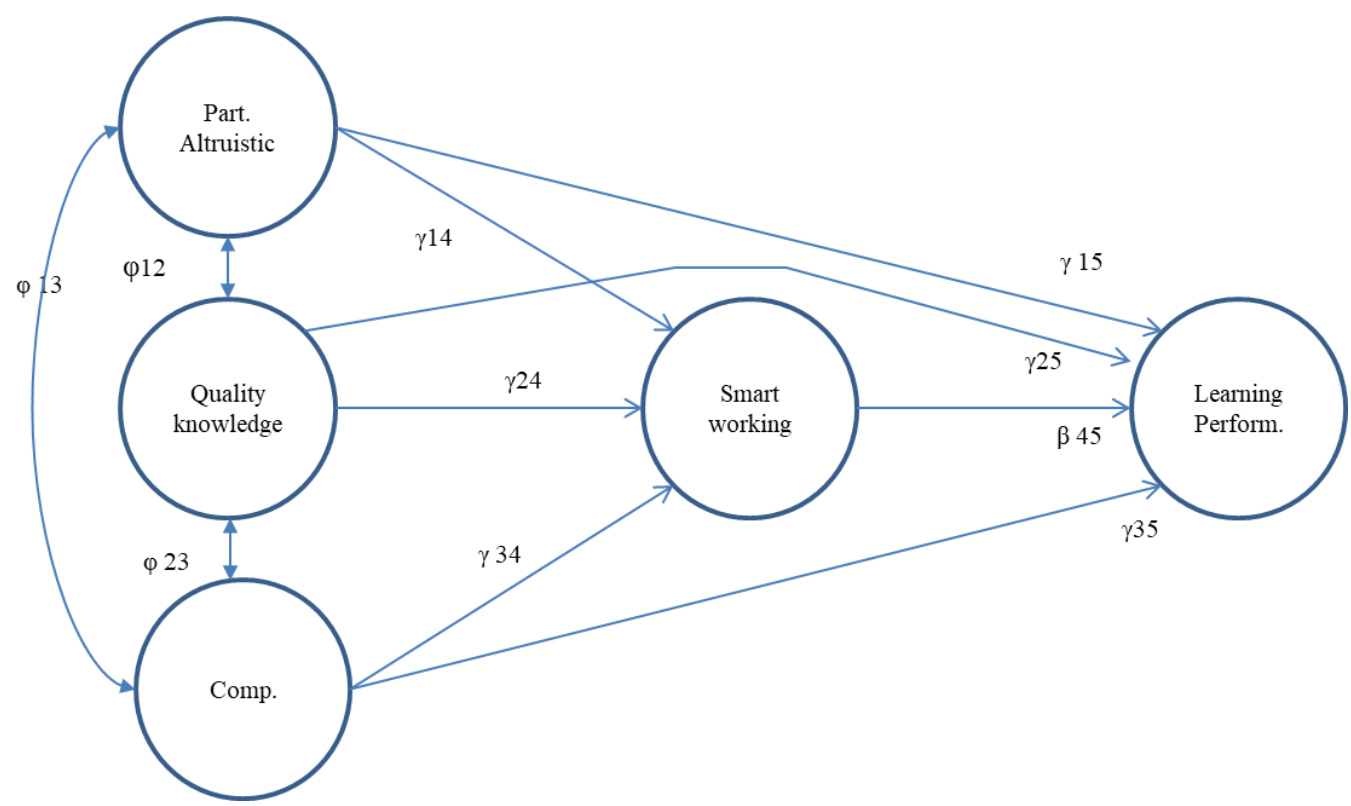

Figure 2. Pathway Hybrid Model

Figure 2 shows the estimated coefficient value of the relationship between variables namely $\varphi 12=$ regression of participatory altruistic toward quality knowledge, $\varphi 13=$ regression of participatory altruistic toward competence, $\varphi 23=$ regression of quality knowledge toward competence, $\gamma 14=$ regression of participatory altruistic toward smart working, $\gamma 24=$ regression of quality knowledge toward smart working, $\gamma 34=$ regression of competence toward smart working, $\gamma 15=$ regression of participatory altruistic toward learning performance, $\gamma 25=$ regression of quality knowledge toward learning performance, $\gamma 35=$ regression of competence toward learning performance, $\beta 45=$ regression of smart working toward learning performance. After knowing the estimated coefficient value, the next step is to calculate the $\mathrm{t}$ value, to determine whether the research model hypothesis is accepted or no accepted.

\section{Results}

Structural model testing is related to evaluation of the coefficients or parameters that show a causal relationship or the effect of one variable on another variable. In this research, testing of the model is carried out to find out how participatory altruistic, quality knowledge, competence and smart working with learning performance. Results of the structural model analysis are shown in Table 1. 
Table 1. Evaluation of Structural Model Coefficients and T-value on the Hypothesis

\begin{tabular}{|c|c|c|c|}
\hline Hypothesis & $\begin{array}{l}\text { Regression } \\
\text { Coefficient }\end{array}$ & T-value & $\begin{array}{l}\text { Result } \\
(t>1.96)\end{array}$ \\
\hline $\begin{array}{l}\mathrm{H} 1 \text { : there is a positive relationship between } \\
\text { competence and smart working. }\end{array}$ & 0.80 & 3.18 & Accepted \\
\hline $\begin{array}{l}\mathrm{H} 2 \text { : there is a positive relationship between } \\
\text { participatory altruistic leadership and smart } \\
\text { working }\end{array}$ & 0.86 & 3.57 & Accepted \\
\hline $\begin{array}{l}\mathrm{H} 3 \text { : there is a positive relationship between quality } \\
\text { knowledge and smart working }\end{array}$ & 0.81 & 4.19 & Accepted \\
\hline $\begin{array}{l}\mathrm{H} 4 \text { : there is a positive relationship between smart } \\
\text { working and learning performance }\end{array}$ & t 0.99 & 3.69 & Accepted \\
\hline $\begin{array}{l}\text { H5 : there is a positive relationship between quality } \\
\text { knowledge and leraning performance }\end{array}$ & 0.91 & 3.62 & Accepted \\
\hline $\begin{array}{l}\text { H6: there is a positive relationship between } \\
\text { participatory altruistic and learning performance }\end{array}$ & 0.88 & 4.61 & Accepted \\
\hline $\begin{array}{l}\mathrm{H7} \text { : there is a positive relationship between } \\
\text { competence and learning performance }\end{array}$ & 0.88 & 4.70 & Accepted \\
\hline
\end{tabular}

Table 3 shows that all proposed hypotheses are accepted significantly. The first hypothesis, namely there is a positive relationship between competence and smart working. Accepted because the t-value obtained was 3.18 and the regression coefficient was 0.80 . The value to be significant because the t-value $>1.96$ and the estimated value is quite high because of the positive relationship between the competence and smart working indicators. In the analysis of structural from standard solution path diagram hybrid model between participatory altruistic and smart working, it can be seen that the second hypothesis is accepted. Because there is a positive relationship between participatory altruistic and smart working. Accepted because the t-value obtained was 3.57 and the regression coefficient was 0.86 . The value to be significant because the t-value $>1.96$ and the estimated value is quite high due to a positive relationship between the participatory altruistic and smart working indicators. Analysis between variables quality knowledge and smart working, it is known that the regression coefficient and t-value obtained show significant results. This can be seen from the regression coefficient of 0.81 which is quite high and t-value of 4.19 which is greater than 1.96. In the structural of standard solution path diagram hybrid model analysis between the variables smart working and learning performance, it is known that the regression coefficient and t-value obtained show significant results. This can be seen from the regression coefficient of 0.99 and $t$-value of 3.69 where the $t$-value is greater than 1.96. In the structural of standard solution path diagram hybrid model analysis between variables quality knowledge and learning performance, it is known that the regression coefficient obtained is 0.91 and the $t$-value is 3.62 which is greater than 1.96. These results indicate that there is a significant relationship between the latent variables quality knowledge and learning performance, so this proves that hypothesis 5 is accepted. Significant results in hypothesis 6 prove that there is a positive relationship between participatory altruistic learning performance, so it can be said that the research hypothesis 6 is accepted. It is known that the regression coefficient and t-value obtained show significant results. This can be seen from the regression coefficient of 0.88 which is quite high and $\mathrm{t}$-value of 4.61 which is greater than 1.96. In the analysis of structural from standard solution path diagram hybrid model between variables competence and learning performance, it can be seen that there is a positive relationship between competence and learning performance. Accepted because the t-value obtained was 4.70 and the regression coefficient was 0.88 . The value is said to be significant because the t-value $>1.96$ and the estimated value is quite high due to a positive relationship between the variables competence and learning performance.

\section{Discussion}

All three variables in research, competence, quality knowledge and leadership will shape smart working lecturer, so that it will provide direction and quality in its learning performance. This condition will directly provide work results, work performance and performance which is positive and tends to increase. The success of a university depends on human resources in doing its work. This is determined by a positive attitude characterized by smart working. Smart working is an adaptive behavior related to the development of knowledge. Smart working is directed to develop and use knowledge in work situations. Smart working is based on the view that intelligence must be considered in the 
context of the situation between other mental preparations, demanding self-confidence, and behavior change and behavior adjustment to the task at hand (Babalola et al., 2016). A good work ethic determines the success and implementation of smart working. Attitudes, behaviors, smart working culture that is collaborated with the development of professionalism into intellectual capital and positive emotional capital for lecturer learning performance. The results of the study by Ferdinand (2004) state that the success of human resources in doing their work is determined by a positive work attitude which is characterized by hard work attitudes, smart work attitudes and aggressive work attitudes (hard-working, smartworking, agreiveness).

The results of this study are supported by the results of research by Widodo (2015) where indicators in the quality of knowledge affect one's intelligence. The three criteria for using knowledge for innovation are credibility, relevance and adaptability. In their research on Knowledge Quality Development Model Based on Knowledge Networks and Cross-Functional Collaboration Towards Innovative Performance found that the first priority of performance development models is to improve the quality of knowledge accurately, objectively, dynamically and reliably. one's intelligence. The equation with this study is a performance review based on the quality of knowledge.

Thus the influence of lecturer competence on learning performance is supported by several research results Competence which consists of variables including professionalism, social, pedagogy, personality stimulates the lecturer to use the skills and potentials that are owned by smart working in carrying out their duties (Harro et al., 2016).

Lecturers will use their abilities as an implementation of the quality of their knowledge to be able to innovate, act and carry out useful activities at the university (Nasir et al., 2018).

This altruistic participatory leadership refers on the concept of leadership that has a voluntary spirit in leading lecturers in the study program, by opening opportunities for lecturers to develop strategies and find solutions to existing problems in the Sipil Engineering Education Study Program which includes several aspects namely decisions, listeners and good hope givers are very important. In the context of learning activities, leadership is very important, because in the world of education is loaded with things that do require someone works with heart, voluntarily doing things that are possible more than its obligations, so that it can be well received in the environment his work With this altruistic participatory leadership expected can provide motivation, foster a conducive situation in the environment job, which is expected to further the lecturer learning performance conducive, besides other factors that support (Kardoyo et al., 2019). Leader's style and power Altruistic participatory is expected to be a role model that can be supervisors for lecturers and have expertise, which will have an impact to the desire of lecturers to be individual learners who will always be improving the competence and knowledge quality positively influences on its performance.

\section{Conclusion}

This research has led to a new concept of learning performance of lecturers. Influence between leadership The quality knowledge, competence of lecturers and smart working on the learning performance of lecturers. Participatory altruistic leadership is expected to be creating conditions conducive to lecturer learning performance. Quality indicator lecturer knowledge which includes the quality of intrinsic knowledge, quality Conceptual knowledge and actionable quality, will influence patterns and innovation lecturers in behaving, acting and implementing in universities and this tends to be affect the performance of lecturers. Thus the lecturer competence which includes pedagogical competence, professional competence, and social competence personality will influence the behavior and performance of lecturers' learning performance. This provides an explanation that lecturer learning performance is influenced by the quality of lecturer knowledge, lecturer competence and participatory leadership altruistic through smart working lecturers.

\section{References}

Babalola, S. S. (2016). The effect of leadership style, job satisfaction and employee-supervisor relationship on job performance and organizational commitment. Journal of Applied Business Research (JABR), 32(3), 935-946. https://doi.org/10.19030/jabr.v32i3.9667

Famakin, I., \& Abisuga, A. (2016). Effect of path-goal leadership styles on the commitment of employees on construction projects. International Journal of Construction Management, 16(1), 67-76. https://doi.org/10.1080/15623599.2015.1130601

Hair, J. F., Risher, J. J., Sarstedt, M., \& Ringle, C. M. (2019). When to use and how to report the results of PLS-SEM. European Business Review. https://doi.org/10.1108/EBR-11-2018-0203 
Hallinger, P., \& Hammad, W. (2019). Knowledge production on educational leadership and management in Arab societies: A systematic review of research. Educational Management Administration \& Leadership, 47(1), 20-36. https://doi.org/10.1177\%2F1741143217717280

Handayani, S., Sugiharto, D., \& Sutarto, J. (2019). Power Influence of Leadership on Lecturer Performance for University Quality Management. Paper presented at the 1st Vocational Education International Conference (VEIC 2019). https://doi.org/10.2991/assehr.k.191217.009

Harro, C. C., Marquis, A., Piper, N., \& Burdis, C. (2016). Reliability and validity of force platform measures of balance impairment in individuals with Parkinson disease. Physical therapy, 96(12), 1955-1964. https://doi.org/10.2522/ptj.20160099

Hussain, G., Ismail, W. K. W., Rashid, M. A., \& Nisar, F. (2016). Substitutes for leadership: alternative perspectives. Management Research Review. https://doi.org/10.1108/MRR-03-2015-0044

Kardoyo, K., Nurkhin, A., \& Melati, I. S. (2018). A Profile of Master-Degree Program Graduates of Economic Education, UNNES: A Tracer Study. Paper presented at the International Conference on Science and Education and Technology 2018 (ISET 2018). https://doi.org/10.2991/iset-18.2018.58

Kardoyo, Pitaloka, L.K., Rozman \& Hapsoro, B. B. (2020). Analyzing Universities Service Quality to Student Satisfaction; Academic and Non-Academic Analyses. International Journal of Higher Education, 9(1), 126-132. https://doi.org/10.5430/ijhe.v9n1p126

Kumpulainen, K., Vierimaa, S.-M., \& Koskinen-Koivisto, E. (2019). Developing Connective Pedagogy in Cultural Research-A Case Study from the Teachers' Perspective in Adopting a Problem-Based Approach in Higher Education. Education Sciences, 9(4), 252. https://doi.org/10.3390/educsci9040252

Liu, R., Cheng, W., Yu, Y., Xu, Q., Jiang, A., \& Lv, T. (2019). An impacting factors analysis of miners' unsafe acts based on HFACS-CM and SEM. Process Safety and Environmental Protection, 122, 221-231. https://doi.org/10.1016/j.psep.2018.12.007

Milhem, M., Muda, H., \& Ahmed, K. (2019). The Impact of Transformational Leadership Style on Employee Engagement Using Structural Equation Modeling (SEM). International Journal, 2(8), 162-173. https://doi.org/10.35631/IJMTSS.280016

Nasir, A. N. M., Ahmad, A., Udin, A., Wahid, N. H. A., \& Noordin, M. K. (2018). Competence Level of Technical Knowledge for Electronic Lecturers in Vocational College, Malaysia. Advanced Science Letters, 24(4), 2796-2798. https://doi.org/10.1166/asl.2018.11062

Pio, R. J., \& Tampi, J. R. E. (2018). The influence of spiritual leadership on quality of work life, job satisfaction and organizational citizenship behavior. International Journal of Law and Management. https://doi.org/10.1108/IJLMA-03-2017-0028

Pourmola, M., Bagheri, M., Alinezhad, P., \& Nejad, P. (2019). Investigating the impact of organizational spirituality on human resources productivity in manufacturing organizations. Management Science Letters, 9(1), 121-132. http://doi.org/10.5267/j.msl.2018.10.011

Purwanto, A., Asbari, M., \& Santoso, P. B. (2019). Does Culture, Motivation, Competence, Leadership, Commitment Influence Quality Performance? Inovbiz: Jurnal Inovasi Bisnis, 7(2), 201-205. https://doi.org/10.35314/inovbiz.v7i2.1210

Saide, S., Indrajit, R. E., Trialih, R., Ramadhani, S., \& Najamuddin, N. (2019). A theoretical and empirical validation of information technology and path-goal leadership on knowledge creation in university. Journal of Science and Technology Policy Management. https://doi.org/10.1108/JSTPM-06-2018-0067

Sarstedt, M., Hair Jr, J. F., Cheah, J.-H., Becker, J.-M., \& Ringle, C. M. (2019). How to specify, estimate, and validate higher-order constructs in PLS-SEM. Australasian Marketing Journal (AMJ), 27(3), 197-211. https://doi.org/10.1016/j.ausmj.2019.05.003

Silva, A. G., Cerqueira, M., Raquel Santos, A., Ferreira, C., Alvarelhão, J., \& Queirós, A. (2019). Inter-rater reliability, standard error of measurement and minimal detectable change of the 12-item WHODAS 2.0 and four performance tests in institutionalized ambulatory older adults. Disability and rehabilitation, 41(3), 366-373. https://doi.org/10.1080/09638288.2017.1393112

Male T., Palaiologou I. (2019) Leadership: Theory and Practice. In: Sustaining the Comprehensive Ideal. Palgrave Pivot, Cham. https://doi.org/10.1007/978-3-030-34156-5_4 
Sugiharto, D. Y. P., Rifai, A., Suripto, S., \& Widhanarto, G. P. (2018). Development Model of Professionalism Guidance and Counseling Teacher. Paper presented at the 4th International Conference on Early Childhood Education. Semarang Early Childhood Research and Education Talks (SECRET 2018). https://doi.org/10.2991/secret-18.2018.43

Sutarto, J., Mulyono, S. E., \& Raharjo, T. J. (2017). Design of Training Based on Needs to Improve Pedagogic Competence of The Tutors. Paper presented at the 1st Yogyakarta International Conference on Educational Management/Administration and Pedagogy (YICEMAP 2017). https://doi.org/10.2991/yicemap-17.2017.17

Widodo., Yuwalliatin, S., Astuti, E., D. 2015. The Development Design of Knowledge Quality Based on Knowledge Networking and Cross-Functional Integration Towards

Yeung, T. S., Wessel, J., Stratford, P., \& MacDermid, J. (2009). Reliability, validity, and responsiveness of the lower extremity functional scale for inpatients of an orthopaedic rehabilitation ward. journal of orthopaedic \& sports physical therapy, 39(6), 468-477. https://doi.org/10.2519/jospt.2009.2971 